\title{
Titania doped triaxial porcelain: Enhancement of strength by controlled heat treatment
}

\author{
SUNIPA BHATTACHARYYA ${ }^{\dagger}$, SWAPAN KUMAR DAS*, KAUSIK DANA and \\ NIRENDRA KRISHNA MITRA ${ }^{\dagger}$ \\ Clay and Traditional Ceramics Division, Central Glass and Ceramic Research Institute, Kolkata 700 032, India \\ ${ }^{\dagger}$ Department of Chemical Technology, Calcutta University, Kolkata 700 009, India
}

MS received 1 September 2005; revised 4 April 2007

\begin{abstract}
Titania doped vitrified triaxial porcelain samples were subjected to controlled heat treatment at different temperatures of 600,800 and $1000^{\circ} \mathrm{C}$ with a specific heating schedule. The results revealed that flexural strength of $800^{\circ} \mathrm{C}$ heat treated sample was significantly enhanced to $60 \mathrm{MPa}$ from its original value of $40 \mathrm{MPa}$. XRD pattern revealed the formation of mullite in the system both before and after heat treatment and the differences in their growth was ascertained through SEM analysis. The present heat treatment process may be useful to produce high strength porcelain body from a common triaxial system.
\end{abstract}

Keywords. Triaxial porcelain; titania; heat treatment; recrystallization.

\section{Introduction}

Mullite formulation starts from the clay in the triaxial porcelain body at as low as $950^{\circ} \mathrm{C}$ by solid state reactions and continues until feldspar melts. Many researchers have investigated the effect of $\mathrm{TiO}_{2}$ on mullite formation in the triaxial system of clay-quartz-feldspar (Kopeikin 1958; Zografou 1968; Chaudhuri 1974; Bhattacharyya et al 2005). Choudhuri (1974) showed that further mullitization in the porcelain body from the large volume of feldspathic glass is possible in presence of $\mathrm{Ti}^{4+}$ which helps to form mullite from the glass by replacing $\mathrm{Al}^{3+}$ in its structure. Davis and Pask (1971) reported that the mineralizing effects of transition metal oxides on mullite formation are quite contradictory. According to some workers (Green and White 1973; Johnson and Pask 1982), the solubility of $\mathrm{TiO}_{2}$ in mullite is in the range of $2-4 \mathrm{wt} \%$, while Schneider et al (1993) and Hong and Messing (1997) observed maximum solubility of $\mathrm{TiO}_{2}$ in mullite to be within the range of 2-6 wt $\%$. Zografou (1968) reported that $1-3 \mathrm{wt} \%$ $\mathrm{TiO}_{2}$ could be tolerated without inhibiting mullitization. Formation of more elongated morphology of secondary mullite crystals due to heat treatment is also reported (Iqbal and Lee 2000; Lee and Iqbal 2001). The present authors (Bhattacharyya et al 2005) in their recent study observed that in a triaxial porcelain body mullite content increased with increase in $\mathrm{TiO}_{2}$ content and no significant effect was observed beyond $6 \mathrm{wt} \%$ addition. In the same study, they also observed a drastic reduction of residual strength after

*Author for correspondence (swapan@cgcri.res.in)
8 cycles of heating at $800^{\circ} \mathrm{C}$ and cooling particularly in $6 \mathrm{wt} \% \mathrm{TiO}_{2}$ containing sample. In the present investigation, $6 \mathrm{wt} \% \mathrm{TiO}_{2}$ containing porcelain samples vitrified at $1300^{\circ} \mathrm{C}$ were subjected to controlled heat treatment at various temperatures $\left(600,800\right.$ and $\left.1000^{\circ} \mathrm{C}\right)$. The primary objective of this study was to promote secondary recrystallization process for the enhancement of strength. The heat treated samples were subjected to flexural strength measurement, phase identification and changes in microstructural features.

\section{Experimental}

The raw materials used in the present study were collected from Indian sources and similar to those used in our earlier work (Bhattacharyya et al 2005) viz. china clay from Rajmahal, Bihar; ball clay from Bikaner, Rajasthan; quartz and feldspar from Ranchi, Jharkand and titania from Emerck India Ltd. One kilogram of original batch was prepared consisting of $37.6 \mathrm{wt} \%$ china clay, $9.4 \mathrm{wt} \%$ ball clay, $23.50 \mathrm{wt} \%$ feldspar, $23.50 \mathrm{wt} \%$ quartz and $6 \mathrm{wt} \%$ of titania. $850 \mathrm{~g}$ of this batch was calcined at $900^{\circ} \mathrm{C}$ and mixed thoroughly with rest of $100 \mathrm{~g}$ uncalcined batch. This mixed batch was granulated with water and compacted at $350 \mathrm{~kg} \cdot \mathrm{cm}^{-2}$ pressure to form rectangular bars of $60 \times$ $14 \times 5 \mathrm{~mm}$ size. Bars dried at $110-120^{\circ} \mathrm{C}$ were vitrified at $1300^{\circ} \mathrm{C}$ by the same method as adopted by the present authors in their earlier work (Bhattacharyya et al 2005). The vitrified samples were first characterized with respect to their linear shrinkage (LS), bulk density (BD), apparent porosity (AP), flexural strength, phases present and microstructural features and then subjected to controlled heat 
treatment at various temperatures $\left(600,800\right.$ and $\left.1000^{\circ} \mathrm{C}\right)$ under specific schedule (figure 1) in an electrically operated laboratory furnace using a on/off control system. After soaking at peak temperature ( $24 \mathrm{~h}$ in all the cases), natural cooling was followed and it took about $20 \mathrm{~h}$ to reach room temperature $\left(30^{\circ} \mathrm{C}\right)$. The code of different batches and its heat treatment temperature is given in table 1.

The samples without and with heat treatment at different temperatures were finally subjected to flexural strength measurement, phase analysis and microstructural evaluation. The physical properties such as linear shrinkage, bulk density and apparent porosity were determined as per standard procedure. Instron $5500 \mathrm{R}$ instrument was used for flexural strength measurement. Philips ' $\mathrm{X}$-Pert Pro' diffraction unit, with secondary monochromator, automatic divergence slit and mixed filter $(\mathrm{Cu}-\mathrm{K} \alpha$ radiation $)$, was used to identify the various phases formed in the experimental samples. For SEM study, samples were polished to $1 \mu \mathrm{m}$ finish with diamond paste after initial grinding with $\mathrm{SiC}$ powder and water. The polished surface of each sample was etched for $3 \mathrm{~min}$ in 5\% HF solution at room temperature $\left(35^{\circ} \mathrm{C}\right)$, washed in water and acetone followed by gold sputter coating (Edwards, Scancoat). SEM (LEO 430i) was used for obtaining secondary electron images.

\section{Results and discussion}

The chemical analysis results of the raw materials used in the present study indicate that china clay, ball clay, quartz

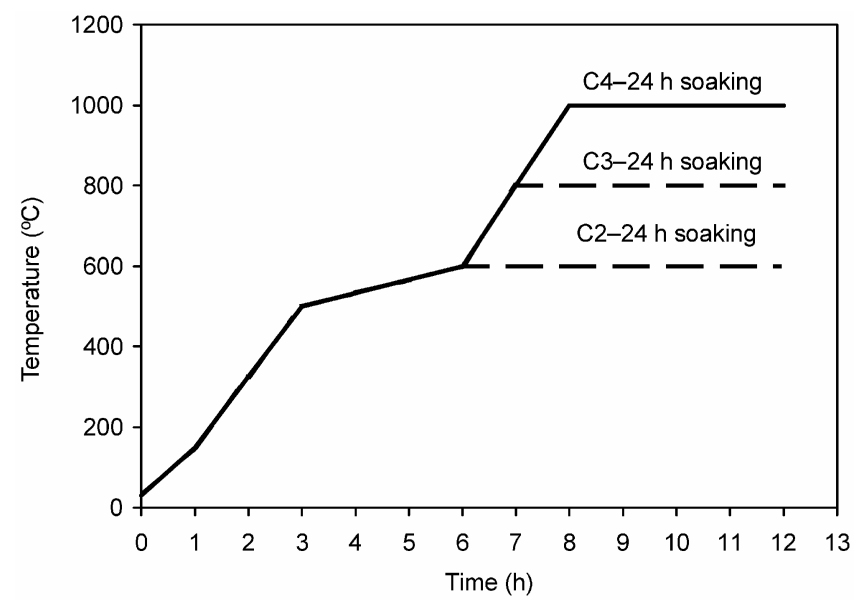

Figure 1. Heat treatment schedule.

Table 1. Batch code and their heat treatment temperature.

\begin{tabular}{lc}
\hline Code & Heat treatment temperature $\left({ }^{\circ} \mathrm{C}\right)$ \\
\hline C1 & No heat treatment \\
C2 & 600 \\
C3 & 800 \\
C4 & 1000 \\
\hline
\end{tabular}

and feldspar are of normal type commonly used in porcelain body. Titania was of pure chemical grade. The physicomechanical properties of the experimental body vitrified at $1300^{\circ} \mathrm{C}$ are given in table 2 .

The results of table 2 indicate that the present experimental body attained its complete vitrification at $1300^{\circ} \mathrm{C}$ with adequate strength (40 MPa) and repeatability of results of our earlier work (Bhattacharyya et al 2005) was observed. Drastic reduction of strength occurred after eight cycles of alternate heating (at $800^{\circ} \mathrm{C}$ ) and cooling in air due to formation of low viscosity glasses in presence of titania. For the enhancement of mechanical properties, the samples were subjected to controlled heat treatment at different temperatures and the results are presented in figure 2 .

From figure 2, it is revealed that the strength is significantly enhanced (60 MPa) when the vitrified sample $(\mathrm{C} 1)$ is heat treated at $800^{\circ} \mathrm{C}(\mathrm{C} 3)$. No improvement in strength is observed for $600^{\circ} \mathrm{C}$ heat treated sample (C2). Sample C4 (heat treated at $1000^{\circ} \mathrm{C}$ ) shows improvement in strength over $\mathrm{C} 1$ but less than $\mathrm{C} 3$. Typical strength controlling factors in porcelain (Carty and Senapati 1998) are volume fraction, particle size, elastic properties, thermal expansion coefficients and phase transformations of the constituent phases. To confirm this, X-ray diffraction and SEM studies were carried out to ascertain the evolution of different phases and their microstructural features. XRD pattern reveals that

Table 2. Physico-mechanical properties of $1300^{\circ} \mathrm{C}$ vitrified experimental body without heat treatment $(\mathrm{C} 1)$.

\begin{tabular}{lc}
\hline Properties & Value \\
\hline Percent linear shrinkage & $13 \cdot 5$ \\
Percent apparent porosity & $<0 \cdot 50$ \\
Bulk density $\left(\mathrm{g} . \mathrm{cm}^{-3}\right)$ & $2 \cdot 30$ \\
Room temperature flexural strength $(\mathrm{MPa})$ & 40 \\
Residual flexural strength $(\mathrm{MPa})$ after eight & 2.50 \\
$\quad$ cycles of alternate heating $\left(\right.$ at $\left.800^{\circ} \mathrm{C}\right)$ and & \\
cooling in air & \\
\hline
\end{tabular}

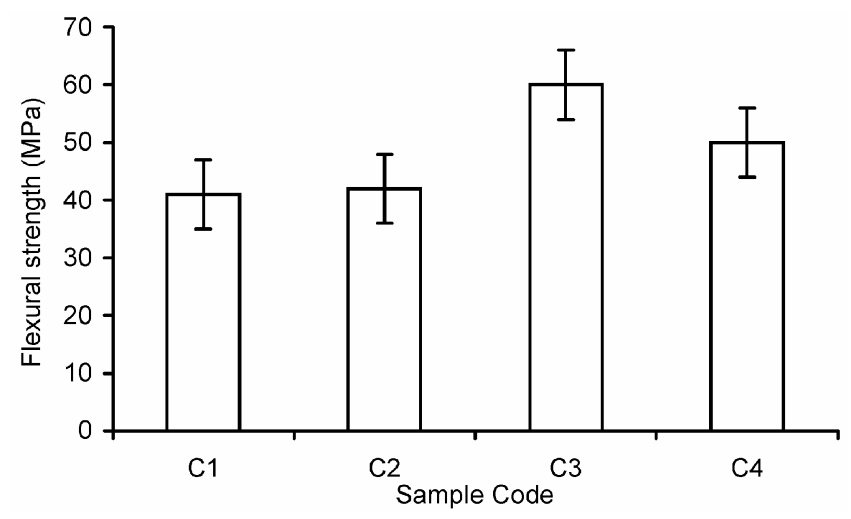

Figure 2. Variation of flexural strength at different heat treatment schedules. 


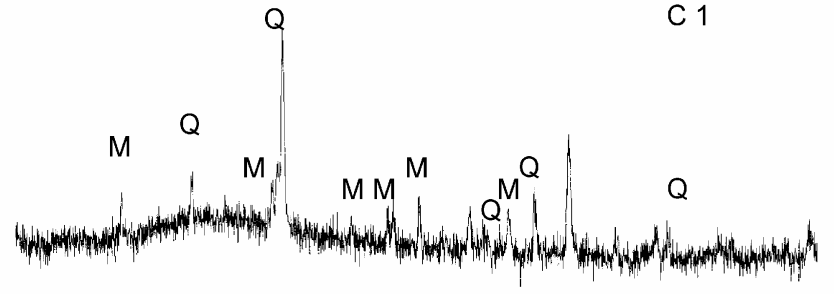

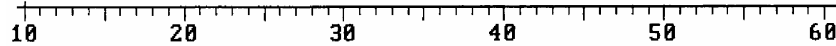

Figure 3. XRD pattern of experimental samples (Q, quartz and $\mathrm{M}$, mullite).

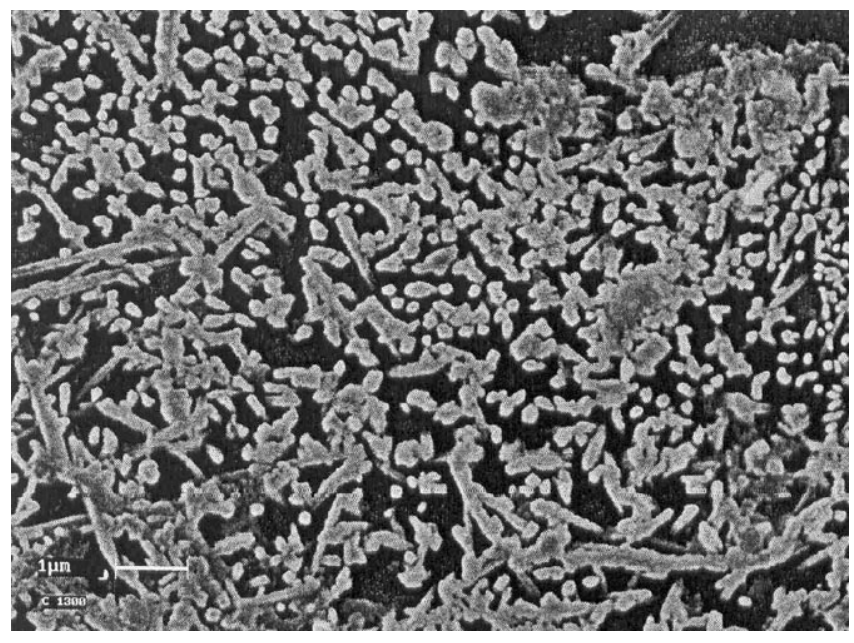

Figure 4. SEM photomicrograph (polished surface) of vitrified sample without heat treatment (C1).

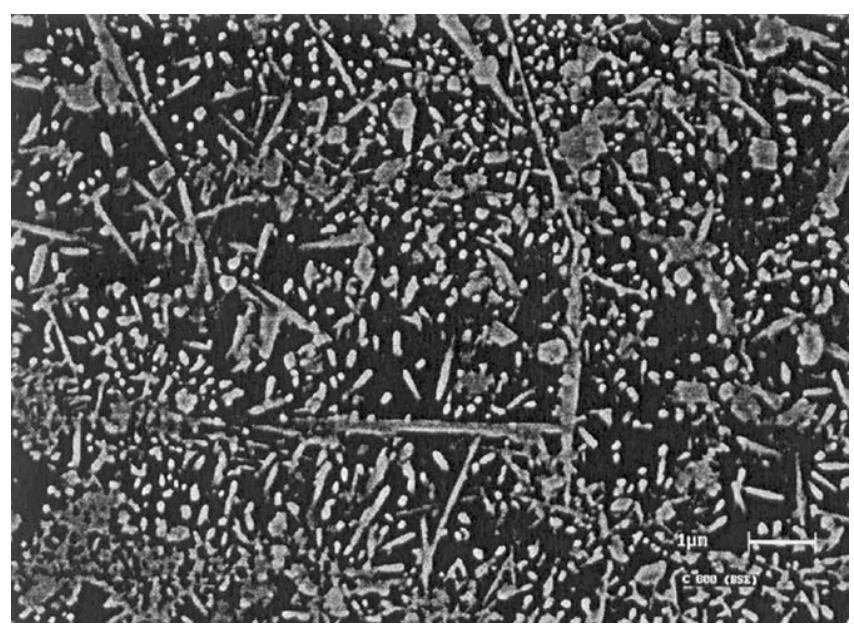

Figure 5. SEM photomicrograph (polished surface) of vitrified sample heat treated at $800^{\circ} \mathrm{C}(\mathrm{C} 3)$.

all the batches show quartz and mullite as the major phases and the patterns of different heat treated samples (viz. C2, $\mathrm{C} 3$ and $\mathrm{C} 4$ ) show similarity to $\mathrm{C} 1$ (figure 3 ) except some sharp mullite peaks appearing on heat treatment due to their increased crystallinity. Thus, it can be inferred that mullite and quartz phase content of different batches were almost similar and flexural strength was nominally affected by it.

SEM photomicrographs were taken on the polished and etched surface of the vitrified specimens to study phase assemblage, grain growth and interlocking of the constituent phases. Photomicrographs of $\mathrm{Cl}$ (figure 4) show the presence of major cubic primary mullite grains with few scattered elongated mullite needles in the feldspathic glass. The SEM photomicrographs of $800^{\circ} \mathrm{C}$ heat treated sample (C3) which has shown maximum strength is represented in figure 5 . It shows increased abundance of fine secondary mullite needles with higher aspect ratio (5.6) compared to $\mathrm{Cl}(2 \cdot 5)$. This higher aspect ratio of secondary mullite in heat treated sample contributed towards enhancement of mechanical strength. The mineralizer $\left(\mathrm{TiO}_{2}\right)$ added to the base composition provides sites for heterogeneous nucleation from feldspathic glass. Nucleation process is more or less complete during vitrification, and during heat treatment, growth of mullite crystals occurs. In presence of titania, substitution of $\mathrm{Al}^{3+}$ by $\mathrm{Ti}^{4+}$ probably in the octahedral sites of the mullite crystals could cause $\mathrm{Al}^{3+}$ vacancy which influences the mass transport and both size and interlocking of the mullite crystals. Thus, heat treatment in presence of titania resulted in controlled crystallization leading to formation of secondary mullite of high aspect ratio and better interlocking, which was responsible for enhancement of mechanical strength.

\section{Conclusions}

From the present study, it may be concluded that the mechanical strength of the titania doped porcelain sample is significantly enhanced by heat treatment at $800^{\circ} \mathrm{C}$ due to secondary recrystallization process. SEM study shows the presence of mullite needles of high aspect ratio in heat treated samples. The presently developed heat treatment process may be useful to produce high strength porcelain body from a common triaxial system for application in special traditional ceramics products.

\section{Acknowledgements}

The authors wish to thank Dr S Ghatak and Dr (Mrs) S Sen, Central Glass \& Ceramic Research Institute, Kolkata, for their valuable suggestions and microstructural study, respectively.

\section{References}

Bhattacharyya S, Das S K and Mitra N K 2005 Bull. Mater. Sci. 28445

Carty W M and Senapati U 1998 J. Am. Ceram. Soc. 813 
Chaudhuri S P 1974 Ceram. Bull. 53 169, 251

Davis R F and Pask J A 1971 Mullite, in high temperature oxides, part-IV refractory glasses, glass-ceramics and ceramics (ed.) A M Alper (New York: Academic Press)

Green C R and White J 1973 Trans. J. Br. Ceram. Soc. 7373

Hong S H and Messing G L 1997 J. Am. Ceram. Soc. 801551
Iqbal Y and Lee W E 2000 J. Am. Ceram. Soc. 833121 Johnson S M and Pask J A 1982 Ceram. Bull. 61838 Kopeikin A A 1958 Steklo Keram 1518

Lee W E and Iqbal Y 2001 J. Eu. Ceram. Soc. 212583

Schneider H et al 1993 J. Mater. Sci. Lett. 121812

Zografou Constantin 1968 Tomind.-Zig. Keram. Rundschau 92478 